\title{
LAW AND THE REGULATION OF FAMILY SECRETS
}

\author{
GAROL SMART* \\ *The Morgan Centre, School of Social Science, University of Manchester. Email: \\ Carol.Smart@manchester.ac.uk
}

\section{ABSTRACT}

This article addresses the changing relationship between traditional legal definitions of motherhood and fatherhood and newer scientific definitions of parenthood. It is acknowledged that procedures like DNA testing have transformed legal interpretations, but in so doing it is argued that the social and cultural significance of kinship has been squeezed out of consideration. There is now an almost unassailable presumption that it is best for a child to know his or her genetic origins, yet there is also evidence that families still keep certain matters (eg donor conception) a secret. These families are increasingly defined as out of step with modern, ethical thinking yet it may be important to understand how such families define a child's welfare. The problem with knowledge about genetic links is that it is not mere 'information' but is powerful knowledge that changes relationships regardless of the wishes of those involved. The fear of such changes may mean families prefer to reject openness, especially if the risks of loss appear too high. These issues are explored through data on family secrets and also through an unusual legal case involving a child who took the decision not to know his own genetic origins. The article concludes that it is important, in the rush to impose transparency and openness on families, that we are aware of the negative as well as positive consequences.

\section{N T R O D U CTION}

I shall lie to [my son $\mathrm{H}]$. I will do that to protect [him]. In my mind my husband is the father...

Mother in Re H (A Minor) (Blood Tests: Parental Rights) - [1996] 3 FCR 201 at 207

If $\mathrm{H}$ grows up knowing the truth, that will not undermine his attachment to his father figure and he will cope with knowing he has two fathers. Better that than a time-bomb ticking away.

Lord Justice Ward, Re H (A Minor) (Blood Tests: Parental Rights) - [1996] 3 FCR 201 at 220

(C) The Author 2010. Published by Oxford University Press. All rights reserved. For Permissions, please email: journals.permissions@oxfordjournals.org. 
In the nineteenth century, when science had nothing to offer and illegitimacy was a social stigma as well as a depriver of rights, the presumption [of legitimacy] was a necessary tool, the use of which required no justification. [...] But as science has hastened on and as more and more children are born out of marriage it seems to me that the paternity of any child is to be established by science and not by legal presumption or inference.

\section{Lord Justice Thorpe, Re H and A (children) - [2002] 2 FCR 469 at 479}

These three quotations capture the issues I wish to discuss in this article. The first two shorter quotations come from the same case which I shall refer to for simplicity as $R e H$. The third quotation comes from a case heard some 6 years later which shall be referred to as $R e H$ and $A$. Both cases involve disputed paternity where a married woman wished her husband to remain the legally acknowledged father of her child. However, in both cases the woman involved had had an affair with another man, and that man disputed paternity, wishing to proclaim himself as the legal father of the child(ren) in question. As Lord Justice Thorpe outlines above, prior to 1969 most children born to married women were treated in law as the legitimate offspring of her husband. Although this presumption was open to challenge such disputes were rare because there was little chance of success in court. This was because few judges felt that making a child illegitimate would be in that child's best interests, and so there was a reluctance to sever the links between a child, the legal father, and the wider paternal family. But perhaps of equal importance was limited ability of scientific blood testing fully to determine paternity. So prior to 1969 , judges would have felt that the consequences of rendering a child illegitimate (and fatherless) were too grave given that paternity could not be established beyond a reasonable doubt. All this, of course, changed dramatically with the rise of DNA genetic testing that is now widely and commercially available. Thus Lord Justice Thorpe reflects, in the third quotation above, on the new and inevitable supremacy of scientific 'fact' over legal supposition or preference. And most certainly he might have added the supremacy of scientific fact over a mother's preferences or her desire to acknowledge one man rather than another as the father of her child.

There are however twin pressures operating in these cases for not only does scientific fact no longer brook any opposition (at least it seems in the mind of judges), but judges increasingly see the revelation of genetic truths as benefiting the welfare of the child. Whereas once such a truth might have been seen to harm the child (eg the child might become disturbed to learn that the man she/he thought was her/his father was not), in current times such truths are increasingly seen as (almost) unequivocally good for children (Blyth and Frith, 2009). Contemporary cases seem full of references to how much better 
it is for a child to know this truth, and to know it sooner rather than later, in order to avoid potential psychological problems later in life (Daniels and Taylor, 1993; Haimes, 1988; Hargreaves and Daniels, 2007). Furthermore, this welfare criterion is linked to a rights based argument, where it is stated that it should be a child's right to know his or her genetic parentage (Eekelaar, 2006). Eekelaar puts forward the case that recognition of children's rights in this regard offers children protection against adult manipulations of truth and also gives (relatively powerless) children a commensurate legal standing with parents in these complex cases. But what does/can this preference for 'truth telling' and rights do when encountering a mother such as the one in Re $H$ above who states quite simply that she will 'lie' about genetic paternity to her child. How should this mother be viewed? Is she oblivious to the 'true' welfare interests of her child by denying genetic paternity? Is she different to the mother who has received a donor egg or embryo and declines to tell her child the scientific facts of conception? And how should parents be viewed who simply fail to get round to telling their children they were conceived by sperm, embryo, or egg donation, even though they may have originally intended to do so? (Konrad, 2005; MacCallum and Golombok, 2007; Murray and Golombok, 2003; Paul and Berger, 2007; Rumball and Adair, 1999). Finally, what might it mean if the child whose interests and rights the courts seeks to protect raises his or her voice to say she/he does not wish to know? Should such a child be obliged to know - for his or her own long-term good?

\section{'A TIME BOMB TICKING AWAY'}

Many family secrets concerning reproduction and conception are, as Lord Justice Ward states so metaphorically, like time bombs ticking away. Yet it may be that some of these incendiary devices, on explosion, cause more harm than others. This means, put simply, that some are more powerful in their consequences than others. Moreover, it may be difficult to judge the impact of revelations in individual cases where relationships may be complex and where different family members operate by different codes of relatedness. So the harm caused by uncovering such a secret in later life may be felt differentially because some family secrets may lose their power to harm over time. This may mean that discovering you are "illegitimate' ${ }^{1}$ at 30 years may have very different consequences to discovering it at 15 or 5 years of age (Jadva et al, 2009). It is also quite possible that the effects of such a secret may be felt differently by different family members (eg cousins, aunts, paternal grandparents, etc.) so it may not be possible to know in advance who will be most hurt or hurt at all. It may therefore be difficult 
to gauge the harm a secret will cause by its exposure some years later or to measure this anticipated harm against the harm caused by forcing exposure sooner rather than later. For example, who really knows with certainty that it is better to tell a specific child that she/he was conceived through donation at the age of 6 months, 2, 5 or 25 years? And who can confidently weigh in the balance the relative harms of a mother telling her husband he may not be the father of her child, which might lead to divorce and hardship, against keeping secret such paternity uncertainty and raising the child in a two-parent household (Turney, 2005)? These examples are of course oversimplifications of the complexities of reproductive secrets, but the point remains that both 'telling' and 'not telling' will have consequences and the idea that the keeping of secrets is detrimental, whereas openness is innocuous, is itself rather problematic (Smart, 2009; Strathern, 1999).

It might of course be argued that harm is not the issue and that it is simply an ethical question where truth telling is always the better option than lying or being 'economical with the truth'. Yet while most people might agree with this in principle, we are aware that absolute truth telling can be difficult, hurtful, and harmful in some instances, particularly within family relationships. In any case, there is a morally hazardous period between formulating the decision to tell and the actual telling of a truth when it concerns matters of conception ${ }^{2}$ or adoption. So with issues such as gamete donation, parents may have to wait some years before they can tell a child about his or her 'origins'. This means that the child is always, to some extent, deceived. But equally, an original conviction that it is best to tell a child might waiver in the face of the possible disruption that might ensue. Murray and Golombok's (2003) research is of relevance to understanding these situations. In their study, 17 egg-donation families with children between 3 and 8 years of age were interviewed about their decisions on telling or not telling their child about their genetic origins. Approximately half $(n=8)$ of the parents had no intention of telling their children, four were undecided, and five planned to tell them in the future. The main reason why the mothers were either against telling or were unsure about telling the truth was because they wanted to protect the child. In other words, their understanding of welfare was contrary to that followed by the English courts in similar cases. While a judge might blithely say, as Lord Justice Ward does above, that a child's relationship to a 'social' parent would not be affected by the discovery that the parent is a genetic stranger, it is clear that these parents (particularly mothers) were not quite so certain. To these parents, the child's discovery signalled possible rejection of them as parents. Equally, the discovery was seen as potentially unbalancing for the child for no 'good' reason. Parents also feared that other family members might view the child differently if true genetic parentage was widely known. This factor 
is often quite ignored in reported cases of paternity disputes, namely how the extended family will react to a child whose parentage is in doubt or is discovered to be conceived outwith the normal expectations of heterosexual marriage. Again Lord Justice Ward confines his remarks in $R e H$ above to the assumption that the child will stay bonded to his social father when he learns that he has a different genetic father; but he does not give consideration to whether the child's 'social kin' on his father's side will stay bonded to him. The ripples that flow through wider family relationships do not feature in these judgements, even though they may feature large in the child's and his/her parents' everyday lives. So returning to the cases in Murray and Golombok's study, although parents wanted to protect themselves from possible harm by keeping the secret, they were also weighing in the balance a wider potential harm to their child and found that this was more significant than truth telling. Some years later, MacCallum and Golombok (2007) found that with couples using embryo donation the same worries recurred. Forty-three percent of the 21 embryo donation families they interviewed had decided not to tell their child about its origins and $24 \%$ were undecided. But interestingly three quarters of the embryo receiving mothers had confided in their own mothers while paternal grandparents were less likely to have been informed. And MacCallum (2009) also found, when she compared this same sample of 21 embryo donation families with 28 adoptive couples, that the donor couples were far less likely to reveal the genetic 'truth' to their children compared with the adoptive parents. With donation families the donor was seen to play no significant role in their lives as a family after the treatment was completed and so, in everyday terms, they ceased to exist.

Interestingly Murray and Golombok (2003) also found that where parents had decided to tell their children about their genetic origins, it was not so much because they adhered to a higher moral standard than other parents, but because other family members already knew about the details of the child's conception. Hence they feared the child would hear inappropriately from someone else and they wanted to be in control of the revelation. Exactly such a situation is described in a case I found recounted in the Mass Observation Project (MOP) at the University of Sussex. ${ }^{3}$ I shall first explain the context of this archival material before exploring the family secrets discussed in the collection.

In 2000, the MOP archivist Dorothy Sheridan sent out a 'directive' to the panel of volunteer narrators (Sheridan et al, 2000) on the question of 'family life' and in that directive she included a question on 'family secrets'. One hundred and sixty-eight women and 50 men replied to this Directive and within that group $85(50 \%)$ of the women and $27(54 \%)$ of the men also wrote about family secrets (see Smart, 
2009). Although many of the secrets discussed in these respondents' accounts concerned secrets that were quite historical, eg, concerning illegitimacy or informal adoptions in the early part of the 20th century, some of the secrets were more contemporary and of ongoing concern. In reading these accounts that spanned at least a century (because some respondents in their 70 s were writing about grandparents who were alive at the turn of the 19th century), it was possible to see the modernisation of some family secrets. Thus in the earlier periods, these secrets were often about illegitimate births, conceptions prior to marriage, and the informal adoption of children into families to disguise the fact a child was born to an unmarried daughter. But current secrets were less likely to be about unwed conceptions, as this was no longer a matter of shame, and were more likely to be about paternity uncertainty ${ }^{4}$ and assisted reproduction. Secrecy over adoption seemed also to have faded, although it is clear that there was still a legacy of 'old' adoption secrets because the discovery of an adoption in a previous generation (before parents were encouraged to tell their children) often meant that people had to live with the knowledge that it was too late to trace wider kin because key people had died.

The first passage I quote below comes from the account written by a retired social worker whom I refer to as Mrs B. Her story captures the contemporary issue of secrecy around assisted reproduction:

I suppose at the moment the family secret that bothers me is the fact of having an IVF grand-daughter. She is now 9, learning the "facts of life" and I think she ought to be told how her life started. There are so many different ways of conceiving and starting life that these matters are common knowledge and should be talked about openly. However, I don't think my grand-daughter has been told and this could be a problem as her cousins know and might talk about it with her. So I feel I ought to raise this with my son but haven't found the right moment. It may be that her parents feel strongly that she shouldn't be told - yet it was never a secret while it was happening. (B 1533 Female, aged 74 , married)

This passage of text from Mrs B captures very precisely the contemporary dilemma surrounding assisted reproduction because often other family members know about the treatment a couple have received at the time of the procedures, yet they find they are drifting into an unwilling collusion with the parents as it becomes clear that the child is not told the circumstances of his/her birth. As I note above in the study of MacCallum and Golombok (2007) of 21 embryo donation mothers, 15 had told at least one family member about the method of conception. Mostly the family member entrusted with the knowledge was the maternal grandmother, in other words someone to whom the mother felt very close. Yet 14 of these 21 mothers were either not going to, or 
were undecided about, telling their child about their conception. It is not clear from the reported study how many mothers who had told a relative were not going to tell their child but it is apparent that some of them were prepared to take the risk of sharing the knowledge with kin while hoping that the secret would be kept quiet. ${ }^{5}$ This is the dilemma that Mrs B in the MOP faced. Her short account reveals the ethical dilemma that knowing this secret caused for her. She appears to have strong views on the 'proper thing to do' yet is anxious about imposing this on her son and daughter-in-law (Finch and Mason, 1993). Such an insistence might, after all, lead to her being excluded from her wider family and loss of contact with her granddaughter. What is more, it seems she is not entirely clear whether the granddaughter has been told, so Mrs B is in a kind of limbo because she does not know whether she can speak openly or not. It may be that the child knows, yet has simply not revealed this to her grandmother. This short account reveals the complex dynamics of such secret keeping in families. The rules for keeping secrets in this context are not clear because it is not only the specific secret that cannot be addressed but also the boundaries of the secret cannot be defined or confirmed because of the taboo that surrounds the whole topic. Mrs B does seem to think that there is 'a time bomb ticking away' in her family and in this regard she might be said to share the views of Lord Justice Ward that living with such an unmentionable and sensitive issue is very uncomfortable - for her at least.

Another narrative in the MOP dealt with the issue of secrecy and gamete donation. This writer (Mrs R) seems (on the face of it) to take a more casual approach to the secret than Mrs B. Yet arguably the potential for the secret to cause harm is greater in this case because the egg donor was the birth mother's own sister rather than a genetic stranger:

In my immediate family, one sister, having been unable to conceive after several bouts of IVF, finally conceived when another sister donated some eggs. This is kept pretty quiet. (R 2247 Female, 52, retired)

Mrs $\mathrm{R}$ does not however make it clear whether the 'keeping quiet' concerns keeping people outside the family in ignorance because they may be shocked and disapproving of the complex kinship relationships created by sister-to-sister donation, or whether it is also a secret within the family such that the child and other kin do not know either.

Although there were few accounts of secrets arising from assisted reproduction in the MOP in 2000, there were many that concerned adoption in earlier times. These stories often recounted forms of 'muddled' kinship, eg a writer might explain that she thought her grandmother was her mother but found out later that her eldest sister was in fact her 'real' mother. Other accounts wrote of confusions about 
whether certain kin were actually cousins or sibling and there seems to have been a frequent lack of clarity over whether siblings were half sibling or full sibling. In some instances, this was because children had not been told that a parent had been married previously and had had a child by that earlier marriage. In other cases, some adopted adults found that when they traced their birth mothers/parents that they actually had full brothers and sisters, not just half sib. These were often poignant cases where a mother gave up her illegitimate child for adoption, but later married the very father of the child and gave birth to subsequent children.

Mrs B, discussed above, was also very concerned about the fact that one of her sons-in-law had been adopted as a child. Her worries were not about the adoption per se, but about the fact that he is unable (and it possibly unwilling) to do much to trace his biological parents:

About adoption - I am concerned that my eldest daughter's husband was an adopted child, therefore her children only know about half their heritage. They have half his genes but don't know anything about his birth. I would like them to know this but he cut himself off from them and his mother who adopted him as a baby refuses to talk about it. It was always a secret, never to be discussed. (B 1533 Female, aged 74, married)

In this passage Mrs B says she would like her grandchildren to know all about their genetic heritage. It is not clear that the grandchildren are particularly interested, but evidently Mrs B feels that they should know and she appears anxious that her son-in-law is not making more forceful efforts to trace his genealogy. Mrs B wants a complete genetic story. Her concern epitomises a modern anxiety about the need to know all about one's genetic heritage lest something unfortunate has been passed down the line that could harm children in later years. But her concern both in this passage and the one quoted earlier indicates, I would argue, something more about the power of family secrets than just altruistic concern. Lord Justice Ward described them as time bombs that will, inevitably, one day explode. Yet it may be more helpful to see them as part of the power dynamics in family life where some people come to share secrets (or knowledge that later becomes secret) and thus can themselves choose whether to reveal it or not. So, in Mrs B's narrative she expresses a sense of awkwardness at knowing something that her granddaughter (probably) does not know and she also expresses concern that her other grandchildren do not know their full genetic inheritance. In this way, she appears to construct herself as the ethical and medical guardian of the extended family. Her son and daughter and their spouses are, by her lights, morally ineffectual and she wants to step in to put the situation to rights. Looked at in this way, we can see that secrets fold themselves into complex power plays between generations and kin. 
I think I was the family secret. Every time I asked about my father I was fobbed off, and only found out [who my father was] when I saw my birth certificate when I was 12 years old. I would not have wished to meet him, given my mother's taste in men. (R 1760 Widow aged 60+)

This short passage of quotation is taken from another account of family secrets found in the MOP. The narrator here condenses a number of complex issues into a couple of sentences. She captures succinctly the social mores of England in 1945 when she was born. She says baldly that she was the secret because illegitimacy was then still so shameful. She lived without a father and was unable to find out anything about him from her mother. Her mother was obviously rather vague about her father and the possible circumstances of her conception during the war. She found out she was illegitimate when she was 12 years old, but she does not provide any details about her father in her short account. It is possible she only discovered his name and date of birth. But she does go on to say that she would not have wished to meet him. This is, of course, the voice of a woman of 60 or more years rather than the 12-year-old child and we cannot assume that she has held this view all her life. Yet it is interesting that in her mature years she adopts this position. It is quite contrary to the more publicly stated views of adults who are really keen to find and meet their genetic parents. She is apparently out of step with modern sensibilities. Perhaps, however, it is important to keep separate two elements in this account. She wanted to know about her father but she did not want to meet him nor, it would seem, to have a relationship with him. So, is it possible to want to 'know about' a father and yet not want to 'relate to' him in a substantive way? If so, are we in danger of conflating these two components when it comes to contemporary interventions in family life? Does 'knowing about' genealogical kin also require the creation of a relationship with them (Strathern, 1999)? Is a new normative standard being created that insists, for children at least, that knowing about is not enough and that emotional and physical closeness is also required?

Concentrating first on knowing about, there is clearly now an established norm, arising mainly from counselling professions and studies of adoptees, that children should know about their biological/ genetic heritage (Carsten, 2000; Freeman et al, 2009; Haimes, 1988; MacCallum and Golombok, 2007). But taking this knowledge to the next stage may be less easy and/or desirable. Carsten's study of adults tracing their birth mothers (and sometimes biological fathers) provides a more complex understanding of this knowing about and the translation of the knowledge into an act of reunion that presages the formation of meaningful bonds (Carsten, 2000). Her study was based on interviews with 13 adults (mostly women) who had undergone 
searches for their genetic parents. Her interviewees wanted to meet their birth mothers and many anticipated an instantaneous bond or sense of deep recognition. But Carsten found that such meetings were often far from deeply meaningful or magical. What became apparent in her interviews was that kinship (in terms of a sense of bonding or affection) was far from automatic and several of her interviewees spoke of being confronted by a stranger. Moreover, once the initial meetings had taken place, many found their relationships became fairly insignificant; often just becoming the exchange of cards at birthdays and Christmas. This suggests, albeit that this was a small study, that the desire to know was strong, but the desire to start or maintain a relationship was less attractive or feasible once the actual genetic kin was encountered. This is an important point to emphasise because in cases of paternity disputes concerning children, the ideal has become one in which the child should not only 'know about' his or her genetic father, but should also form a relationship. This requirement is significantly different to the situation facing adults who trace genetic kin later in life. These adults can them remove themselves from the fledgling relationship if they find it sterile, difficult, or unpromising. Children however may not have this choice if it is thought that such a relationship is in their long-term interests.

So, in contemporary paternity cases, there is a presumption about the value of both 'knowing about' and the subsequent 'relating to'. In donor cases, this is not yet a presumption. Rather in these cases a child can discover non-identifying information about donors but cannot necessarily trace and meet the donor. However, there are now websites ${ }^{6}$ that do make it possible for children born from sperm donation to attempt to make contact with their genetic/donor fathers and arguments are already being formulated that children not only should know about but also should have relationships with donor kin (Freeman et al, 2009). For example, Wallbank (2002) has made this argument in relation to surrogacy. Her point is that the gestational mother in a surrogacy arrangement should be regarded as just as much a mother as the commissioning mother and that it is likely to be harmful to the child's sense of self to be denied contact with this 'first' mother. The link between knowledge of parentage and the imposition of bonds is therefore taking shape - at least where children are concerned.

THE CASE OF RE D (RE D (PATERNITY) [2007] 2 FLR 26)

This case is an interesting example of the problems that can arise from the presumption that knowing about genetic kin is good and that forming a relationship with them is even better. The case of $\operatorname{Re} D$ occurred in 2006 and concerned a boy aged 11 years known as T. The 
boy's mother was aged 14 years at the time of his birth and was in Local Authority Care. She identified the putative father, and the young man she identified, who was also in care, acknowledged paternity. But the mother could not look after $\mathrm{T}$ and so he went to live with his paternal grandmother (Mrs D) who was eventually granted a residence order for T. Living with T and his grandmother was T's full brother and a cousin. The case notes report that $T$ never saw his mother and only occasionally saw his father, so his main and most significant carer was his paternal grandmother. On the occasion of T's 10th birthday, a person known to the family presented a man (known as Mr E) to T as his 'real' or genetic father. This came as a complete surprise to $\mathrm{T}$ and his grandmother Mrs D. Subsequent to this event, Mr E applied to the court for residence of $\mathrm{T}$ and contact orders and an order for parental responsibility. In effect $\mathrm{Mr} \mathrm{E}$ wanted to establish his genetic relationship to T through a DNA test and, on the strength of that evidence, wished to remove the child from his grandmother's care and to raise him as his son. The possibility that this might happen was reported as being deeply shocking to T. But a positive DNA test would have had even more powerful consequences than this. A DNA test which proved that Mr E was T's father would have meant that Mrs D was no longer his 'real' grandmother, his brother would no longer be his 'real' brother, and his cousin no longer his 'real' cousin. In effect there would be a wholesale de-kinning of T's family. In other words, he would have lost - symbolically and possibly in practice - more kin than he would have gained by the sudden appearance of a stranger who happened to be his genetic father.

In the case report, it is noted that $\mathrm{T}$ was a disturbed child who was going through many psychological difficulties and so the challenge to his family life came at a very problematic time. Although he was 11 years at the time of the hearing, it was deemed that he was not 'Gillick competent'. This meant that he was not thought to have sufficient cognitive capacity to fully understand the consequences of his own decisions and so the court felt able to make decisions about his welfare without following his stated wishes. And his stated wish was most vehemently that there should be no DNA test to establish whether or not $\mathrm{Mr} \mathrm{E}$ was his genetic father. His grandmother, Mrs D, was also strongly against the test because she feared she would lose her grandson to $\mathrm{Mr} \mathrm{E}$ if it was shown she was not genetically related to T. However, her views were treated as significant only in as much as it was felt she might influence $\mathrm{T}$ against the test, or at least to the extent that she might not encourage him to find out the genetic truth. In other words, she was seen only as a potential obstacle to the establishment of genetic truth and her feelings and fears were not treated as relevant in their own right.

From the point of view of how courts and public policy seek to manage family secrets, this case is particularly interesting. The boy $\mathrm{T}$ 
was at an age when he could voice his views very clearly, but he was not deemed cognitively competent enough for his views (that were contrary to public policy) to become decisive. But, unlike most children in cases of disputed paternity, he was not an infant. He could not therefore simply be ignored. The courts could not very easily unhear or discount what he said. In this case, the judge (and the social worker and guardian ad litem) would have been keenly aware of the consequences of forcing T to undergo such a test; forcing him to know the 'truth' and then forcing him to relate to the stranger who was (possibly) his genetic father. With a younger (voiceless) child, the courts could simply have assumed that imposing such knowledge, such contact, and such a relationship would be a 'good thing'. As Mr Justice Hedley stated:

... the general approach is that it is best for everyone for the truth about a disputed paternity to be known. The classic statement of that is to be found in the judgment of the Court of Appeal in Re H and A (Children) [2002] EWCA Civ 383, [2002] 1 FLR 1145. I acknowledge at once that that should be the guiding principle in all the cases with which the court deals. It has obvious merit, not least the general proposition that truth, at the end of the day, is easier to handle than fiction and also it is designed to avoid information coming to a young person's attention in a haphazard, unorganised and indeed sometimes malicious context and a court should not depart from that approach unless the best interests of the child compel it so to do. Re D (Paternity) [2007] 2 FLR 26 at 32

However, in this case, the child $\mathrm{T}$ is complaining loudly that he does not want to know the truth. He is actually happier with 'the fiction' than the truth. For $\mathrm{T}$ the fiction would mean keeping his grandmother, his brother, and cousin, and remaining living with them in some security. The truth would plainly jeopardise this. Hence for $\mathrm{T}$, the genetic truth (if it showed that Mr E was his father) would be much harder to handle and apparently he was not prepared to risk the hurt and disruption it would bring in its wake.

This left the trial judge, Mr Justice Hedley, with a problem since he could not abandon his certainty that truth was better than fiction. So he devised a way in principle to preserve the ideal of genetic truth while not going so far as to force T to undergo a DNA test and to risk forfeiting his family. He realised the havoc the latter course of action would have wreaked, so he ordered that DNA samples be taken from both Mr E and $\mathrm{T}$, but he postponed the order concerning $\mathrm{T}$, allowing it to rest for the time being but making it capable of restoration at a later date when $\mathrm{T}$ might change his mind. The consequence of this decision was that Mr E could not pursue his application for a parental responsibility order and contact with $\mathrm{T}$ (he had already withdrawn his application for residence). $T$ therefore could remain with his grandmother until such time as he might decide that he would like to know whether Mr E was 
in fact his genetic father. Of course, if $\mathrm{T}$ left this decision until he was in his late teens, he would be in a position to discover his genetic parentage without being obliged to form a relationship with Mr E. But what is less clear is what impact the uncertainty about his paternity might have on his relationships with his grandmother, brother, cousin, and also the man he always assumed was his father.

The tendency for public policy, with its enthusiasm for DNA testing, to assume that (genetic) truth is better than (relational) fiction means that the addition of more genetic kin through these means is inevitably seen as producing a positive outcome for children (and possibly for adults). Yet children live in webs of relationships that are delicately interconnected and adding more relatives may disrupt and even break some of these links. Konrad has spoken of 'local moralities of information disclosure and non-disclosure within and across the generations' (2005: 162) and this concept of local moralities is relevant here. My argument is not that law or public policy should simply accept and follow such local norms, but rather that it is misplaced to be shocked to discover that not everyone in family relationships might think that genetic truth is an unassailable guiding principle.

\section{KINNING AND DE-KINNING: KNOWING AND NOT KNOWING}

If secrets can be said to carry certain 'magical' properties and may sometimes come to life in the form of the evanescent gift, then knowing what not to know and living one's life in relation to 'active not knowing' are ethico-cultural animations that give fundamental shape and meaning to sociality. (Konrad, 2005: 161)

It is part of Konrad's argument that, from an anthropological perspective, people are engaged in practices of active not-knowing around family matters that are problematic or potentially disruptive. Part of growing up or simply relating to others may be learning what 'not to know'. A vivid example of what might be seen as patrolling the boundaries between what is acceptable to say and acceptable to know appeared in the Mass Observation Project referred to above. This short account is about the family of some relatives of the narrator $(\mathrm{H})$ where it was often joked about that one child of the family must have been the offspring of another man. Such jokes may not be uncommon, especially where there is no physical likeness or there are strong temperamental differences. However, in this case the suspicions proved to be true:

It used to be a family joke that one sister must have had another dad - but this was always denied in a horrified way. Then on her deathbed their mother told her sister that she did indeed have a different father. He'd been killed at Anzio and had he lived their mother was going to leave her husband for him. She kept it a secret from everyone all her life - covering up the fact by going 
to visit her husband who was stationed in Ireland as soon as she knew she was pregnant. Unfortunately she did not give the sister enough info for her to trace her real father's family so she is left in limbo. (H 1703 Female, married, aged 53)

The point about this story is that the mother knew the child was not her husband's and she had to police the suspicions (or possibly just vague intuitions) of other family members throughout her adult life. We are not told whether the woman who discovered her illicit paternity was shocked by the knowledge or whether her intuited understandings were merely confirmed. But the chances are that if this was indeed a family joke, then other relatives must also have had some knowledge or doubts and must have either avoided asking or realised that it was better to live in (partial) ignorance.

This is perhaps a case of what Konrad refers to as 'ethico-cultural animations'. This means that in the context of this particular birth, presumably in 1944 before the Second World War was over, and the immediate post-war decades, family members and friends would have avoided the a serious mention of the topic if they had suspicions. It could be spoken of by close family as a joke because a joke would only confirm the complete unlikelihood of an adulterous conception. Yet the joke also kept alive the possibility that it could be true. So these various ways of circumnavigating the issue (by avoidance, by denial, by joking) were also ways of establishing the local morality of that family, which in turn was embedded in the local moralities of post-war Britain where undoubtedly many other children were also born from such liaisons. The future of all the children of the family would have been put at risk had the mother confessed. Moreover, the status of the family within its kin network and wider networks would have been compromised. Although many, at that time and in that place, might have known how common such conceptions were, equally the dominant morality would have required condemnation of the mother at least, and possibly all her children.

Looking to past family secrets often allows us to be sociological about them, rather than moralistic or judgemental. Indeed often these become simple stories of the human condition, invoking sympathy and understanding. Take these examples from the MOA:

Looking at the cases I have cited, they are to do with people's perceptions at the time; about ignorance and lack of contraception; about what was considered 'correct'. (R 1227 Female, aged 56, married, retired teacher)

In her late teens she fell pregnant and her parents put her straight in a home for unmarried mothers and had the baby adopted. She really hopes the baby will come into her life one day. Terribly sad. (W 853 Female, aged 60+, self employed) 
I don't know why there had to be so much secrecy, it was not a very terrible secret; my grandmother was legally married to X. Unless he didn't die at all, and her second marriage was bigamous. I will never know. (B 1665 Female, aged 66 , single retired clerk)

These secrets would have been just as powerful in their time as contemporary ones about assisted conception and paternity uncertainty are now. So the question that we need to pose in the present is whether we should incorporate a sociological understanding into contemporary debates rather than limiting these insights to historical accounts. Should we accept the strong legal presumption that genetic/DNA certainty gives rise to the requirement that families must organise themselves according to genetic 'truth'? Or should there be a greater appreciation that such simple truths may at times damage complex kinship ties? This is the point that Strathern made in 1999 when she argued:

... if we do wish to pursue openness then we should know that part of the stimulus comes from certain politics of communication (open information for a free society; truth for the sake of justice), and not from systematic investigation into kinship practices. (1999: 80)

Although Strathern was clear that she was not arguing in favour of secrecy for secrecy's sake, she was making an argument about the ways in which ideals of transparency and complete freedom of information could operate in damaging ways in systems of kinship. Knowledge of genetic connectedness is not 'mere' information; rather it is deep knowledge about one's kinship network and also about one's self. As she argues, one has no option but to deal with it once it is known and this is why, she suggests, family members are fearful of the consequences of such knowledge. In other words, the mother who says she is worried that the knowledge of being donor conceived may 'upset' a child has every reason to be concerned.

There are no easy answers to these dilemmas, but it remains probable that many parents will continue to resist the modern requirement to give priority to genetic kinship and that it may be a disservice to them to imagine that such sensibilities arise from dubious moral motives rather than a desire to care for and protect their children. However, as Strathern (1999: 83) wryly remarked, 'I doubt whether these observations of mine have much future' and a decade later it seems that she was correct and I would predict that my observations also will fall on stony ground.

\section{A C K N OWLED GE MENTS}

Mass Observation material reproduced with the kind permission of the trustees of the Mass Observation Archive, University of Sussex. 


\section{NOTES}

${ }^{1}$ The old legal concept of illegitimacy no longer applies in a strict sense. However, people still have a clear understanding of the social meaning of discovering your mother's husband is not your biological father when he was believed to be.

${ }^{2}$ For example should a woman tell her partner/husband that she has had a brief affair the very next day, the day she discovers she is pregnant, or shortly after the birth of the child, or never given that the child might be her partner's. At what point is trust most broken?

${ }^{3}$ The Mass Observation Project (formerly known as the Mass Observation Archive) is based at the University of Sussex. It is a collection of writings, started in 1937, from the general public who were, originally, invited to record their daily observations of life around them. In more recent times, the project has adopted the practice of sending out to their volunteer writers special 'directives' that are specific questions deemed pertinent at a given moment (eg Prince Charles' wedding) or by social researchers. The archive is a very particular kind of data set that, until recently, was not really thought to be of value to sociological research. However, see Savage (2007) for a full discussion of the value of this special collection.

${ }^{4}$ It is very hard to know about paternity uncertainty in the past. I have already noted the 'presumption of legitimacy' that was only removed in the 1969 Family Law Reform Act. Because of this presumption, very few husbands would have raised their concerns without very firm evidence, and mothers would have had every motivation to keep their fears quiet. Lovers too would have had little incentive to raise a claim for paternity. The position of unwed mothers was also very complex. Before the availability of blood tests, she would have found it difficult to establish paternity at all, let alone to distinguish between possible genetic fathers if there was more than one possibility. And even the availability of blood tests hardly changed the situation since a mother could refuse permission for a blood sample to be taken from her child. The likelihood however is that paternity uncertainty is not a new phenomenon; rather what is new is the extent to which it is becoming a site of litigation.

${ }^{5}$ Other mothers in the study $(n=6)$ had taken the precaution of not telling family members about their treatment and so did not depend on collusion by others should they decide not to tell.

${ }^{6}$ http://www.dcnetwork.org: This website advocates openness and gives advice about telling children and avoiding 'damaging secrets'. http://www.acebabes.co.uk: ACeBabes. http://www .ukdonorlink.org.uk: A pilot voluntary contact register to link donors and donor conceived children. http://www.tangledwebs.org.uk/tw: A support site for donor conceived people who have just found out. They focus on the negative consequences of gamete donation.

\section{REFERENCES}

Blyth, E. and Frith, L. (2009) 'Donor conceived people's access to genetic and biographical history', International Journal of Law, Policy and the Family 23(2), 174-91.

Carsten, J. (2000) "Knowing where you've come from": ruptures and continuities of time and kinship in narratives of adoption', Journal of the Royal Anthropological Institute 6, 687-703.

Daniels, K. and Taylor, K. (1993) 'Secrecy and openness in donor insemination', Politics and the Life Sciences 12(2), 155-70.

Eekelaar, J. (2006) Family Law and Personal Life, Oxford: Oxford University Press.

Finch, J. and Mason, J. (1993) Negotiating Family Responsibilities, London: Routledge.

Freeman, T., Jadva, V., Kramer, W. and Golombok, S. (2009) 'Gamete donation: parents' experiences of searching for their child's donor siblings and donor', Human Reproduction 24(3), $505-16$.

Haimes, E. (1988) 'Secrecy: what can artificial reproduction learn from adoption?', International Journal of Law, Policy and the Family 2(1), 46-61.

Hargreaves, K. and Daniels, K. (2007) 'Parents dilemmas in sharing donor insemination conception stories with their children', Children E Society 21, 420-31.

Jadva, V., Freeman, T., Kramer, W. and Golombok, S. (2009) 'The experiences of adolescents and adults conceived by sperm donation: comparisons by age of disclosure and family type', Human Reproduction 24(8), 1909-19.

Konrad, M. (2005) Nameless Relations, Oxford: Berghahn Books.

MacCallum, F. (2009) 'Embryo donation parents' attitudes towards donors: comparison with adoption', Human Reproduction 24(3), 517-23. 
MacCallum, F. and Golombok, S. (2007) 'Embryo donation families: mothers' decisions regarding disclosure of donor conception', Human Reproduction 22(11), 2888-95.

Murray, C. and Golombok, S. (2003) 'To tell or not to tell: the decision-making process of eggdonation parents', Human Fertility 6 (2), 89-95.

Paul, M. and Berger, R. (2007) 'Topic avoidance and family functioning in families conceived with donor insemination', Human Reproduction 22(9), 2566-71.

Rumball, A. and Adair, V. (1999) 'Telling the story: parents' scripts for donor offspring', Human Reproduction 14(5), 1392-9.

Savage, M. (2007) 'Changing social class identities in post-war Britain: perspectives from massobservation', Sociological research Online 12(3) 29 May.

Sheridan, D., Street, B. and Bloome, D. (2000) Writing Ourselves: Mass-Observation and Literacy Practices. New Jersey: Hampton Press.

Smart, C. (2009) 'Family secrets: law and understandings of openness in everyday relationships', Journal of Social Policy 38(4), 551-67.

Strathern, M. (1999) Property, Substance and Effect: Anthropological Essays on Persons and Things. London: The Athlone Press.

Turney, L. (2005) 'Paternity secrets: why women don't tell', Journal of Family Studies 11(2), 227-48.

Wallbank, J. (2002) 'Too many mothers? Surrogacy, kinship and the welfare of the child', Medical Law Review 10, 271-94. 